\title{
Exploring Political Risk in Offshoring Engagements
}

HANSEN, CARSTEN; Cranfield School of Management

Mena, Carlos; Michigan State University Eli Broad College of Business,

Skipworth, H; Cranfield University, School of Management

\begin{abstract}
This research focuses on the analysis of political risk in the context of offshoring decisions. The study uses the Repertory Grid Technique (RGT), which entails a series of semistructured interviews exploring key political risks experiences across offshoring engagements. The research extends the spectrum of political risk analysis in the context of offshoring engagements, and explores the varied impact of political risk across business activity types.

The research identifies five key political risks affecting offshoring engagements and highlights the moderating effect of specific offshoring activity types Business Process Outsourcing (BPO), Information Technology Outsourcing (ITO) or Knowledge Process Outsourcing (KPO) on political risk implications. The research explores the conditioning effect of activity specific exposure to political risk and enhances the explanatory ability of the Transaction Cost Economics (TCE) constructs, offering a novel operationalization of the political risk component of external uncertainty.

From a practical perspective, the research highlights the need for developing managerial tools to improve monitoring and identification of risks. The key practical contribution is the development of differentiated political risk typologies that can capture the nuances of external risks in offshoring, allowing for more accurate risk assessment of offshoring decisions.
\end{abstract}




\section{INTRODUCTION}

Offshoring is often driven by the objective of finding more cost effective production or processing solutions by identifying and exploiting cost arbitrage between regions, including low cost skilled labour, low cost raw material and other economic factors (Walker and Weber, 1984; Lewin and Peeters, 2006; Ellram et al., 2008; Tate, et al. 2009). Therefore, offshoring initiatives have traditionally focused on cost reductions by relocating subsidiary facilities, or outsourcing production or services to suppliers in low cost countries. Evolving research further indicates that offshoring is not only driven by cost considerations, but also increasingly by accessibility to ideas and human capital or to gain access to developing markets (Ellram et al., 2008; McIvor, 2009; Tate and Ellram, 2009). However, offshoring decisions also expose firms to many risks, which in turn can have a detrimental effect on firm's supply chain performance (e.g., Wagner and Bode, 2008; Wilson, 2007) and firms' financial performance (e.g. Hendricks and Singhal, 2003; Altay and Ramirez, 2010; Li et al., 2015; Zsidisin, Petkova and Dam, 2016)

In an extensive review of the supply chain risk literature, Ho et al. (2015) identify macrorisks, which include natural risks and man-made risks, such as war, terrorism and political instability, as one of the key risk categories that have so far received limited attention. In this research we address this gap by investigating the link between political risk and offshoring activities. Specifically we seek to identify and categorize events that constitute political risk and how these risk manifestations affect offshoring operations. The study paves the way for a deeper and more diversified understanding of political risk impact on offshoring, contributing to the development of more resilient supply chains (Christopher and Peck, 2004; Ambulkar, 2015; Tukamuhabwa, et al. 2015).

As emphasized by Kobrin (1979: 77), 'we need to be concerned not with political events but their potential manifestations as constraints upon foreign investors'. From this notion follows that changes in the political environment, that do not change the business environment, do not represent political risk. Nor is political risk for one firm necessarily a risk for another firm, meaning that political risk is firm specific (Robock, 1971). The correlation between outputs of the political system (and social environment), and the corresponding business risk implications provide a framework for a more detailed classification of political risks.

The proposed research will be guided by the following research question: 
What are the key contingent political risk types impacting on offshoring engagements?

Following this introduction we present a review of the literature on offshoring and its links to political risk. This is followed by a description of the research methods used, including data collection and analysis consideration. The findings are then presented and discussed in light of the extant literature. The final section presents the conclusions and contributions of the study.

\section{LITERATURE REVIEW}

\section{$2.1 \quad$ Offshoring strategies}

The term offshoring strategies refer to the geographic transfer of a company's operations outside the borders of its home country (Grappi et al. 2013), fundamentally meaning exposure to a foreign environment. The extant literature in this field reaffirms the relevance of analysing extrinsic risks such as political instability and legal infrastructure in the vendors' host countries, including differences in legislation towards intellectual property rights, labour contracting and employment law (Weiss and Azaran, 2007). The need to conduct country risk analysis for offshoring engagements, looking at political risk that can impact on partner company performance, is well established (Goodman and Ramer, 2007). Despite the relevance of researching external uncertainties relating to offshoring, limited research has been focused on assessing the specific risk sources and consequences of political risks facing offshoring firms across different business activities and engagement forms (Alon and Herbert, 2009).

While offshoring has traditionally been associated with the manufacturing industry, the offshoring of business services has seen a similar dramatic growth over the years, transforming the way businesses are managing their operations in an increasingly globalized world (Ellram, et al., 2008; Tate and Ellram, 2009). The offshore service industry has been driven by technology improvements lifting constraints on geography, time and communication expense, allowing suppliers to easily connect with customers across the globe, giving service offshoring both scale and momentum (Lewin and Peeters, 2006; Modarress, 2007; Tate and Ellram, 2009). As technologies in ICT introduced digitalization, services no longer needed to be done in situ and it is possible to separate segments of 
service processes for offshoring. The growth rate of service offshoring underlines the relevance of expanding research towards investigating industry specific risks.

Offshore outsourced services are often classified into Information Technology Outsourcing (ITO), Business Process Outsourcing (BPO), and Knowledge Process Outsourcing (KPO) (Lacity et al. ,2008; Youngdahl and Ramaswamy, 2008). The three categories compound specific properties that potentially may vary in their exposure to the external environment, hence the following research will maintain a category specific distinction between transactional services, mainly ITO and BPO, and complex research-based services represented by KPO.

\section{$2.2 \quad$ Transaction cost economics (TCE) and offshoring}

The Transaction Cost Economics (TCE) approach focuses on the cost of each contract i.e. the process of supplier evaluation, negotiation and monitoring (Coase, 1937; Williamson, 1995; Williamson, 2002). These costs relate to the 'transaction' of the process, and appear both when engaging with markets (outsourcing) and in a hierarchy (internalization). The TCE approach fundamentally focuses on the identification of the governance structure that entails the least cost per transaction. The transactions take place in an environment based on information asymmetry and bounded rationality (Ellram et al., 2008) and the characteristics of transactions focus on asset specificity, uncertainty, performance measurement and frequency (Williamson, 1979; 2000). Empirical studies have supported the basic principles of transaction cost variables (Aubert et al., 2004) and TCE attributes are considered key in determining the governance form of the contract. Based on this logic, TCE predicts outsourcing to prevail for transactions of low-frequency, characterized by a low level of uncertainty, with few transaction specific investments and simple performance measurement requirements. Alternatively, when frequency is high, the firm will prefer to internalize the transaction and enter the market through a subsidiary (Madhok and Tallman, 2006).

The TCE framework provides an indication of when certain products or services are internalized and when firms prefer outsourcing to the market, based on relative cost and risk considerations associated with a given operation. The key consideration of TCE is to select the governance form that will minimize the sum of transaction costs (Zhao et al., 2004). 
The cumulative understanding of the TCE determinants in relation to offshoring is mixed and inconclusive, with disparate results and inconsistent findings with a range of methodologies applied (Zhao et al., 2004). In 2004, Zhao published a meta-analytical review, including a review of 38 empirical studies from the period 1986-2002, based on transaction cost theory. The study offers a comprehensive review of empirical findings from prior studies in regard to the predictive abilities of TCE, including the application of external uncertainty (Zhao et al., 2004). Zhao's et al. (2004) meta-analysis highlights the impact of moderators on predictions, including the effect of the country of origin, location and industry type in various TCE based studies. The moderating effect of country of origin refers to findings suggesting that the effects of cultural distance, international experience and advertising intensity vary significantly, depending on firm's home country. The effect of industry type is generally found to moderate all TCE variables, suggesting that TCE determinants are industry specific.

While TCE points to external uncertainty as a decisive factor in offshoring, it has not been conclusive on how and when external uncertainty affects the strategic offshoring decision, and how perception of external uncertainty, and corresponding firm behaviour, might vary depending on industry and firm specific attributes.

\subsection{Political risk manifestations in offshoring}

A review of the extant literature on political risk in offshoring was used to map the key political dimensions and their underlying manifestations. Table 1 presents an overview of key political risk dimensions, identified through a systematic review of the political risk literature comprising of 115 key papers published in the period 1970 - 2015. The table presents the individual research focus areas within the political risk domain using the overall risk categorizations presented by Miller (1992), Agarwal and Feils (2007) and Rao and Goldsby (2009) as well as the work of Busse and Hefeker (2007). Following Agarwal and Feils (2007), we have included not only political but also economic variables as part of a comprehensive political risk framework. 
Table 1. Political risk typology dimensions from the extant literature

\begin{tabular}{|c|c|}
\hline Political instability & $\begin{array}{l}\text { Political instability and turmoil (Brewer, 1983; Coplin and O'Leary, 1983; } \\
\text { Goodman and Ramer, 2007; Liuhto et al., 2009; Oetzel, 2005; Robock, } \\
\text { 1971; Wade, 2005; Herath and Kishore, 2009; Kobrin, 1981; Kumar and } \\
\text { Sosnoski, 2009; Rios-Morales 2009; Ho et al., 2015); election upheaval } \\
\text { (Oetzel, 2005); changes in political system and stability of ruling party } \\
\text { (Agarwal and Feils, 2007); and internal conflict (Busse and Hefeker, 2007); } \\
\text { instability of neighbour countries (Oetzel, 2005; Tummala and Schoenherr, } \\
\text { 2011; Ho, et al. 2015) and external regional threats (Busse and Hefeker, } \\
\text { 2007). }\end{array}$ \\
\hline $\begin{array}{l}\text { Instability of socio- } \\
\text { economic } \\
\text { environment }\end{array}$ & $\begin{array}{l}\text { Social stability or socio-cultural differences (Leavy, 1984; Ho, et al. 2015); in } \\
\text { terms of considering the level of ethnic divide and religious tension (Busse } \\
\text { and Hefeker, 2007); the presence of socio-political grievances (Busse and } \\
\text { Hefeker, 2007); or in terms of consequence and focusing on social unrest } \\
\text { (Liuhto et al., 2009; Sameer Kumar et al., 2009) and law and order } \\
\text { (Gholami 2012). More recently research has considered unemployment } \\
\text { (Liuhto et al., 2009). }\end{array}$ \\
\hline $\begin{array}{l}\text { Macro-economic } \\
\text { instability }\end{array}$ & $\begin{array}{l}\text { Level of foreign debt (Agarwal and Feils, 2007); currency exchange } \\
\text { fluctuations and stability of exchange rates (Agarwal and Feils, 2007; } \\
\text { Herath and Kishore, 2009; Liuhto et al., 2009; Oetzel, 2005) }\end{array}$ \\
\hline Policy predictability & $\begin{array}{l}\text { Frequent changes of government policy and regulation (Agarwal and Feils, } \\
\text { 2007; Brewer, 1993; Miller, 1992; Oetzel, 2005; Tummala and Schoenherr, } \\
\text { 2011; Ho, et al. 2015) including issues such as: fiscal and monetary reforms } \\
\text { (Miller, 1992); price controls (Miller, 1992); trade restrictions (Miller, } \\
\text { 1992); nationalization (Miller, 1992); barriers to earnings repatriation } \\
\text { (Miller, 1992). }\end{array}$ \\
\hline $\begin{array}{l}\text { Institutional capacity } \\
\text { limitations }\end{array}$ & $\begin{array}{l}\text { Corruption (Busse and Hefeker, 2007; Rios-Morales 2009; Wade, 2005); or } \\
\text { corrupt local government (Oetzel, 2005); bureaucracy (Busse and Hefeker, } \\
\text { 2007); or quality of bureaucracy (Gholami, 2012; Herath and Kishore, } \\
2009 \text { ), or degree of red tape; (Agarwal and Feils, 2007). }\end{array}$ \\
\hline Legal unpredictability & $\begin{array}{l}\text { Legal predictability (Busse and Hefeker, 2007); accountability (Herath and } \\
\text { Kishore, 2009; Gholami, 2012); privacy rules (Gholami, 2012), loss of } \\
\text { intellectual property rights - (Weiss and Azaran, 2007; Sameer Kumar et al., } \\
\text { 2009; Herath and Kishore, 2009), compliance risk, relating to local laws and } \\
\text { regulations, and their impact on offshoring activities (Narender, 1997; } \\
\text { Weiss, 2007; Kumar, et al., 2009). }\end{array}$ \\
\hline
\end{tabular}

A number of indices produced by global institutions can support the assessment of business risk including: the Global Competitive Index (GCI), Country Policy and Institutional Assessment (CPIA), The Worldwide Governance Indicators (WGI), Ease of doing business (World Bank), Heritage Foundation's Economic Freedom Index (EFI), Corruption Perception Index (CPI), Bertelsmann's Transformation Status Index (TSI) and Opacity Index, Political Constraint Index. While these indices can provide a general indication of the level of risk that can affect business 
operations in a particular country, none of them drills down on the specific political risk and how they can influence offshoring decisions.

This research focuses on identifying and categorizing political risk experience in offshoring engagements and determine the level of functional impact on business activities. The research will identify both political risk manifestations and the perceived impact on business activities to provide a deeper understanding of political risk dynamics in offshoring operations.

\section{Research method}

The research design is focused on the risk perceptions of practitioners consistent with the risk management literature (e.g. Zisidin and Wagner, 2010), which suggests that risk is experienced as a matter of subjective assessment as represented in the individual perception, as the detection and assessment of risk still requires thinking, judgment and decision-making by an individual (Zuckerman, 2007). In a managerial context, it is further suggested that it is the aggregation and interaction of these individual assessments, in relatively small organizational groupings, that drive business strategies (Smith, 2008).

On this basis the research design focused on the risk perceptions of offshoring practitioners, as these perceptions are assumed to form the basis for managerial decision-making on offshoring considerations. The key informant is therefore the practitioner, either at the level of offshoring manager or advisor, being aware of political risk manifestations across the offshoring project. The study follows a line of previous research of supply chain risk focussing on reviewing managerial perceptions in an attempt to assess and manage corresponding risks. Ellis et al. (2010) suggest that it is the perceptions of risk, rather than objective measures, that drive buyers' behaviour. Further, a study across five organisations (Zsidisin and Wagner, 2010) showed that practitioners' perceptions of risk from suppliers (as well as the risk that emanates from the overall market in which suppliers compete) are a good indicator of how often that risk actually occurs in the form of supply disruptions. In contrast, practitioners' perceptions of risks from the extended supply chain were negatively associated with actual supply disruptions; therefore perceptions of supplier risks beyond the first or second tier may not be reliable. Consequently, it was judged to be reasonable to study risk perceptions of the first or second tier suppliers and the associated supply market. 
Nevertheless, it is acknowledged that the risk perception does not necessarily constitute objective reality (Smith, 2008). To limit this challenge the research applies an evidencebased approach by eliciting political risk manifestations that have had a direct impact on the offshoring operations by focusing on actual offshore engagement cases. By focusing on engagement-specific political risk events, which the informants were directly involved in, the research limits eliciting generic perceptions of risk that the individual manager may have solicited from the general environment. This approach is designed to limit heuristic bias in terms of identifying the actual political risk manifestations experienced. In terms of rating the impact of risk manifestations, the assumption is that whether or not the risk perceptions of the practitioners are accurate, they remain relevant as they become true in their consequence.

The research was conducted through the method of semi-structured interviews with individual offshoring practitioners responsible for establishing, maintaining or advising on extended service chains. As a basis for exploring the underlying constructs of risk perceptions the method of Repertory Grid Technique (RGT) was applied for data extraction and analysis.

\subsection{Implementation of the Repertory Grid Technique (RGT)}

The Repertory Grid analysis method, stems from Personal Construct Theory (PCT) introduced by George Kelly (1955) as a form of structured interviewing, enabling the respondents to articulate their views on complex issues (Goffin et al., 2006; 2012; Stewart, et al., 1981). The PCT framework is based on the notion that in order to make sense of the world people develop rules by which they view and categorize situations, people, relationships and objects, and almost any phenomenon with which they are confronted. The approach assumes that all individuals develop and test constructs as a way of explaining and anticipating events, and that these constructs will be constantly updated, as they prove useful or less useful in interpreting events (Goffin, 2009). RGT has been utilized at least 78 times in management studies in the period 2002-2012 (Goffin, et al., 2012), and it has been applied in a number of business contexts including marketing (Lemke, et al. 2011; Marsden and Littler, 2000), human resource management (Anderson, 1990; Goffin, 1994; Senior and Swailes, 2004) and operations and supply chain management (Goffin et al., 2006; 2012; Lemke, et al., 2003; Mangan et al., 2004; Vandevelde and Van Dierdonck, 2003). 
The following subsections outline the design of the Repertory Grid Approach, as applied for this study, and the interview script is included in Appendix 1.

\subsubsection{Eliciting elements}

Following an introduction to the research objective and methodology, the interviewees were asked to identify up to six offshore outsourcing engagements that they were involved in where their firm experienced political risk exposure that affected the company's operation. These cases were then classified in terms of activity type, host location, buyer location, industry and entry mode type, and written on random pre-numbered cards (I.e. 5; $1 ; 4 ; 3 ; 2 ; 6)$.

\subsubsection{Eliciting constructs}

For the purpose of eliciting risk constructs, groups of three cards (triads) were selected and presented to the interviewee who was asked to compare them. The elements were presented using the dyadic method where two elements are changed for every presentation (Goffin, 2009).

A key component of construct elicitation is the question posed with each triad. The interviewer asked "please think about how two of these cases are similar or different from the $3^{\text {rd }}$ in terms of impact on your offshore outsourcing operation". The interviewee explanations of how two of the elements are similar and different from the third, constitute the interviewees risk constructs, or the attributes on which the interviewee differentiates between the risks.

\subsubsection{Rating elements}

Following the extraction of the risk constructs, the interviewee was asked to rate the triad elements on a pre-decided scale against each specific risk construct, including all other elements (outsourcing engagements) and enter on the pre-prepared grid against a 1-5 scale. Previous studies have highlighted that while various scales have been used in repertory grid testing, the choice of number of points on the scale is situational i.e. if the respondents are sophisticated they can deal with more complicated scales (Goffin, 1994). While the 1 to 5 scale is most common, previous research has applied both seven or nine-point scales to present greater opportunity for discriminatory judgment (Hudson, 1974, cited in Goffin, 
1994). On this note the pilot phase concluded that the 5 point-scale was best understood by respondents and therefore determined the best fit for the proposed study.

\subsection{Data collection}

Access to outsourcing practitioners was facilitated through the International Association of Outsourcing Practitioners (IAOP); the leading professional association for organizations and individuals involved in outsourcing and offshoring, and with a community of more than 120,000 members worldwide. The identification of interviewees through the pool of IAOP members supports the notion of systematic sampling and verifiable data collection, reinforcing credibility of the research project in line with academic standards. Furthermore, the cross-industry and geographical scope of membership allows for sample diversification, minimizing country bias and further enhancing generalizability of the findings.

As the research seeks to identify the political risk experience and impact perceptions of significance among individual offshoring practitioners, a qualitative interview approach following the RGT was applied. This technique for data extraction and analysis was used as the primary tool for exploring the underlying constructs of risk and the perceptions of impact on offshoring operations. In total 25 interviews were conducted, involving 91 offshore engagements, which are the main unit of analysis for the study.

There were two essential tools for interviewing: the interview script (Appendix 1) and the pre-prepared blank grid. The script includes the introductory explanation for the interviewee and the question to be asked as each triad is presented. The blank grid is annotated with constructs and respective ratings during the interview accordingly. Hence each interview generates one grid.

\subsection{Sample distribution}

An initial pilot phase involved 5 non-Repgrid open-ended interviews with key informants in order to garner general views about political risk manifestations and their impact on offshoring. These interviews helped to confirm the relevance of political risk for offshoring decisions and the availability of data (i.e. multiple cases) for full Repgrid interviews. 
The main phase of data collection involved a total of 25 interviews with outsourcing practitioners during the period between April 2013 and August 2014, all lasting between 45-70 minutes. Of the 25 interviewees, 16 represented North American-based companies (64\%), 7 European (28\%), one Australian firm (4\%), and one from Malaysia (4\%). All the participants were in senior positions and involved in outsourcing for a minimum of 10 years. The regional distribution of the sample cases of offshore outsourcing engagements, presented in Table 2, indicates a global spread covering all major regions of economic activity. The samples were diversified across industries with the main industry segment being pharmaceuticals (19.7\%), banking and financial services (14.3\%), healthcare industry, software development industry (13.2\%), web based consumer industry (6.6\%), telecoms (5.5\%), public utilities (5.5\%), insurance \& re-insurance (4.4\%) and the gaming industry $(4.4 \%)$.

The interviews yielded a total of 91 offshore outsourcing engagements or events with 32 BPO engagements, 33 ITO engagements and 26 KPO engagements (as shown in Table 3). In addition to the 91 offshore cases, an additional 6 events were considered onshore outsourcing engagements, meaning that both companies are based within the same country, and hence removed from the sample pool.

Participants were selected based on their level of seniority and experience in outsourcing. All the participants were in senior positions and involved in outsourcing for minimum 10 years. Positions included Director, Vice President of Operations, Operations Manager and Outsourcing Manager. In addition, 5 interviews were conducted, which did not yield a Repgrid matrix and therefore not included in the analysis, however included as a source of background information.

Table 2: Regional distribution of sample cases

\begin{tabular}{|l|l|l|l|}
\hline Host region & No. events & $(\%)$ & Host countries \\
\hline South Asia & 28 & 30.8 & India, Bangladesh \\
\hline East Asia & 17 & 18.7 & China, Philippines, Vietnam \\
\hline Europe (EU) & 16 & 17.6 & $\begin{array}{l}\text { Latvia, Estonia Croatia, Hungary, Poland } \\
\text { and Romania, UK, France, Germany }\end{array}$ \\
\hline
\end{tabular}




\begin{tabular}{|l|l|l|l|}
\hline South \& Central America & 9 & 9.9 & Argentina, Brazil, Costa Rica and Mexico \\
\hline Europe (Non-EU) & 8 & 8.8 & Belarus, Russia and Ukraine \\
\hline North America & 7 & 7.7 & Canada \\
\hline $\begin{array}{l}\text { Middle East and North } \\
\text { Africa }\end{array}$ & 3 & 3.3 & Egypt, Oman \\
\hline Sub-Saharan Africa & 2 & 2.2 & Kenya, South Africa \\
\hline Australia & 1 & 1.0 & Australia \\
\hline Total & 91 & 100 & \\
\hline
\end{tabular}

Table 3: Overview of cases by offshoring activity

\begin{tabular}{|c|c|c|c|c|c|c|}
\hline \multirow{2}{*}{ No. Interviewees } & \multicolumn{3}{|c|}{ Offshoring activity } & \multirow{2}{*}{$\begin{array}{l}\text { Total Offshore } \\
\text { Engagements }\end{array}$} & \multicolumn{2}{|c|}{ Offshore entry mode } \\
\hline & BPO & ITO & KPO & & $\begin{array}{c}\text { Owned } \\
\text { (Insourcing) }\end{array}$ & $\begin{array}{c}\text { Contract-based } \\
\text { (Outsourcing) }\end{array}$ \\
\hline 25 & 32 & 33 & 26 & 91 & 19 & 72 \\
\hline
\end{tabular}

The last 5 interviews (20\% of respondents) yielded 7 constructs, namely: Exchange rate fluctuations, Organized Crime, Organized Labor \& Transport Strikes, Restrictive Labor Laws, Institutional Bureaucracy, Corruption and Loss of IP. All of these constructs had been identified repeatedly by previous respondents indicating that the point of theoretical saturation had been reached.

\subsection{Data analysis}

All the interviews were recorded and the Repgrid matrixes transcribed and compiled in a database for analysis. Each interview was carefully coded and the findings were categorized in accordance with the overall parent political risk classification established in the literature review. The 70 risk constructs were then grouped according to sub-political categories with risk description and associated operational risk implications to enhance the 
understanding of the risk nature. Table 4 presents a couple of examples of how the data was coded and categorized.

Table 4: Examples of quotes from two sub-categories

\begin{tabular}{|c|c|c|}
\hline Political Risk Category & $\begin{array}{l}\text { Political Risk Sub- } \\
\text { category }\end{array}$ & Examples \\
\hline Policy Predictability & $\begin{array}{l}\text { Change of industry and } \\
\text { data management } \\
\text { regulatory framework }\end{array}$ & $\begin{array}{l}\text { "I can confirm that they very often change the guidelines, so for instance } \\
\text { if you say that in XX country it takes } 40 \text { days to get this approval because } \\
\text { that was the case last time. Often you will be told, no sorry, we just } \\
\text { changed that last week and now it is } 90 \text { days. So the handling times over } \\
\text { there change plus the specifications on what needs to be submitted } \\
\text { fluctuates a lot compared to other locations". } \\
\text { "As new regulations emerge the pricing structure changes due to the new } \\
\text { data retention and licenses requirements". }\end{array}$ \\
\hline Institutional Capacity & Corruption & $\begin{array}{l}\text { "We wish to avoid the exposure of management staff to unethical } \\
\text { practices with possible reputational and legal implications, and seek to } \\
\text { train managers in handling these situations". } \\
\text { "Corruption is a reflection of different ground rules and detracts from the } \\
\text { outsourcing activity being a success". }\end{array}$ \\
\hline
\end{tabular}

The frequency of mention was then calculated based on the risk sub-groupings across the 91 offshoring cases by summing the number of times the sub-risk category had been specifically mentioned in an interview grid. To determine the average risk impact ratings that interviewees assigned to each construct sub-category, the impact ratings were added for the individual risk constructs, comprising a construct sub-category. This number was then divided by the number of times the individual risk constructs were mentioned.

While frequency of mention is often used as a measure of importance this interpretation has been criticized as frequently mentioned constructs can be "obvious, easily articulated, and of low importance" (Griffin and Hauser, 1993). A more reliable approach to determine key construct categories is to complement frequency of mention with a second criterion, average normalized variability (ANV). When a construct category has an ANV that is greater than the variability of constructs, this indicates that the interviewees differentiate more strongly between the different constraints. If the construct category has an ANV that is lower than the variability of constructs, then this indicates that interviewees rated the outsourcing cases similarly on a constraint (Goffin et al., 2012). Calculating the ANV requires the variability figures from different grids to be normalized to make them comparable. The average number of risk constructs per grid was 4.64, which resulted in an average variability of constructs at $(100 / 4.64=21.55)$. This method has been used in 
Repgrid to suggest that a construct category with an ANV higher than the average ANV, in this case 21.55, indicates that the construct differentiates more strongly between the different respondents (Goffin, 2012).

Using the software Idiogrid, a Principal Components Analysis (PCA) (Jolliffe, 2002) was run to see which of the political risk sub-categories were most closely associated with the various offshoring typologies i.e. ITO, BPO and KPO. Firstly, the average risk ratings were determined for each risk category, stratified by offshoring activity. This was done by isolating the grids by activity and then within those graphs, identifying the risks mentioned that are part of a given construct category, extracting the risk rating assigned by the interviewee, summing up the total number and then finally, dividing the summed number by the total number of times the constraint was mentioned. This process was repeated for the three offshoring activities and across all constructs categories. The information was then entered into the Idiogrid software to capture which construct categories are associated most strongly with the offshoring activities.

\section{Descriptive Findings}

To present a consolidated overview of the key findings, the results of the 91 offshore engagements were inserted into an overall matrix presenting the political risk categories (Table 5). The table provides an overview of the sub-categories of Risk Constructs from the Repertory Grid Interviews, highlighting risk sub-categories mentioned by $\geq 25 \%$ of respondents following previous RepGrid research (Goffin et al., 2006; Goffin et al., 2012; Lemke, Goffin, and Szwejczewski, 2003). The table also includes details of all the subcategories that emerged from the interviews as well as frequency of mention, perceived impact and ANV. The table is split into three sections (indicated by shading), the top section includes the key constructs which have above average ANV ( $>21.55)$ and frequency of mention above 25\% (Organized labour strikes was included as a key construct despite a $24 \%$ frequency of mention, due to the high perceived impact value of 3.17). The second section includes constructs with frequency of mention above $25 \%$ but below average ANV. The final section includes those constructs with 'frequency of mention' below $25 \%$. 
Table 5. Risk constructs classified by frequency of mention

\begin{tabular}{|c|c|c|c|c|c|c|c|}
\hline No & $\begin{array}{l}\text { Parent } \\
\text { Political Risk } \\
\text { Category }\end{array}$ & $\begin{array}{l}\text { Sub-category } \\
\text { Political Risk }\end{array}$ & Political Risk Constructs & $\begin{array}{l}\text { Freq. of } \\
\text { mention } \\
\qquad \%)\end{array}$ & $\begin{array}{l}\text { Freq. of } \\
\text { mention } \\
\text { (No.) }\end{array}$ & $\begin{array}{l}\text { Perceived } \\
\text { Impact } \\
(1-5 \\
\text { scale })\end{array}$ & ANV \\
\hline 1 & $\begin{array}{l}\text { Policy } \\
\text { Predictability }\end{array}$ & $\begin{array}{l}\text { Home- } \\
\text { country risk }\end{array}$ & $\begin{array}{l}\text { - Client Country - Change in Audit } \\
\text { - Regulations } \\
\text { - } \text { Restrictive immigration laws } \\
\text { - Client Country - Privacy Rules } \\
\text { requirements } \\
\text { - } \text { - Work visa processing } \\
\text { - Home-country risk } \\
\end{array}$ & 48 & 12 & 3.21 & 24.24 \\
\hline 2 & $\begin{array}{l}\text { Institutional } \\
\text { Capacity }\end{array}$ & $\begin{array}{l}\text { Host country } \\
\text { bureaucracy }\end{array}$ & $\begin{array}{l}\text { - Institutional bureaucracy } \\
\text { - } \text { Processing of visa applications } \\
\text { - License Regime } \\
\text { - } \text { Bureaucratic rigidness } \\
\text { - } \text { Delay in visa applications } \\
\text { - Import/export clearance } \\
\text { - Under resourced institutions } \\
\text { - } \text { Delayed approval processes }\end{array}$ & 48 & 12 & 3.06 & 29.58 \\
\hline 3 & $\begin{array}{l}\text { Institutional } \\
\text { Capacity }\end{array}$ & Corruption & $\begin{array}{l}\text { - } \text { Corrupt practices } \\
\text { - } \text { Risk of management exposure to } \\
\text { corruption } \\
\text { - } \quad \text { Business ethics } \\
\end{array}$ & 40 & 10 & 2.70 & 21.75 \\
\hline 4 & $\begin{array}{l}\text { Policy } \\
\text { Predictability }\end{array}$ & $\begin{array}{l}\text { Predictability } \\
\text { of labour } \\
\text { regulations }\end{array}$ & $\begin{array}{l}\text { - Changing restrictive labour laws } \\
\text { - Changes in HR regulations } \\
\text { - Changing minimum wages } \\
\text { - } \quad \text { Regulatory changes on labour } \\
\text { - Unstable labour law/Practices } \\
\text { - Changing safety rules }\end{array}$ & 32 & 8 & 3.03 & 22.92 \\
\hline 5 & $\begin{array}{l}\text { Socio- } \\
\text { economic }\end{array}$ & $\begin{array}{l}\text { Organized } \\
\text { Labour Strike }\end{array}$ & $\begin{array}{l}\text { - National/state labor strike } \\
\text { - National/state transport strikes } \\
\text { - On-site labour strikes }\end{array}$ & 24 & 6 & 3.17 & 21.83 \\
\hline 6 & $\begin{array}{l}\text { Policy } \\
\text { Predictability }\end{array}$ & $\begin{array}{l}\text { Change of } \\
\text { industry and } \\
\text { data } \\
\text { management } \\
\text { regulatory } \\
\text { framework }\end{array}$ & $\begin{array}{l}\text { - } \quad \text { Change of regs. on data storage } \\
\text { - Change regulations - Compliance } \\
\text { - } \quad \text { Changing rules and regulations } \\
\text { - } \quad \text { Policy predictability - data secur. } \\
\text { - Change in reg. framework } \\
\text { - } \quad \text { Unpredictable reg. changes } \\
\text { - Industry policy change }\end{array}$ & 40 & 10 & 2.90 & 17.18 \\
\hline 7 & $\begin{array}{l}\text { Legal } \\
\text { Predictability }\end{array}$ & Loss of IP & $\begin{array}{ll}\text { - } & \text { Loss of IP } \\
\text { - } & \text { IP - Reverse Engineering } \\
\text { - } & \text { IP - Breach of confidence } \\
\text { - } & \text { Changing IP policy framework } \\
\text { - } & \text { IP - Legal Enforcement } \\
\end{array}$ & 40 & 10 & 2.21 & 19.07 \\
\hline 8 & $\begin{array}{l}\text { Legal } \\
\text { Predictability }\end{array}$ & $\begin{array}{l}\text { Contract } \\
\text { enforcement } \\
\text { \& Legal } \\
\text { Transparency } \\
\text { risks }\end{array}$ & $\begin{array}{l}\text { - } \\
\text { - } \quad \text { Lack of institutional capacity to } \\
\text { - } \text { enforce contracts } \\
\text { - } \text { Lack of political will or culture to } \\
\text { - } \text { Soverce contracts } \\
\text { - Laws and regulations / contract } \\
\text { - Legal risk liabilities } \\
\text { - Transparency in legal framework }\end{array}$ & 36 & 9 & 2.54 & 15.18 \\
\hline 9 & $\begin{array}{l}\text { Macro- } \\
\text { economic }\end{array}$ & $\begin{array}{l}\text { Currency } \\
\text { Fluctuations }\end{array}$ & $\begin{array}{l}\text { - Currency fluctuations } \\
\text { - Exchange rate fluctuations }\end{array}$ & 28 & 7 & 2.19 & 17.08 \\
\hline 10 & $\begin{array}{l}\text { Political } \\
\text { Instability }\end{array}$ & $\begin{array}{l}\text { Geo-political } \\
\text { Risk }\end{array}$ & $\begin{array}{l}\text { - Geo-political Risk } \\
\text { - Geo-political instability }\end{array}$ & 12 & 3 & 3.33 & 31.93 \\
\hline 11 & $\begin{array}{l}\text { Policy } \\
\text { Predict }\end{array}$ & $\begin{array}{l}\text { Revenue } \\
\text { repatriation }\end{array}$ & $\begin{array}{l}\text { - Limitations to repatriation of } \\
\text { Revenues }\end{array}$ & 4 & 1 & 4.00 & 33.30 \\
\hline
\end{tabular}




\begin{tabular}{|c|c|c|c|c|c|c|c|}
\hline 12 & $\begin{array}{l}\text { Policy } \\
\text { Predict } \\
\end{array}$ & $\begin{array}{l}\text { Audit } \\
\text { regulations }\end{array}$ & - External Audit requirements & 4 & 1 & 3.33 & 25.00 \\
\hline 13 & $\begin{array}{l}\text { Socio- } \\
\text { economic }\end{array}$ & $\begin{array}{l}\text { Wage } \\
\text { Inflation }\end{array}$ & $\begin{array}{l}\text { - Wage inflation } \\
\text { - Inflation of cost of living } \\
\end{array}$ & 20 & 5 & 3.12 & 19.56 \\
\hline 14 & $\begin{array}{l}\text { Political } \\
\text { Instability }\end{array}$ & $\begin{array}{l}\text { Host } \\
\text { Government } \\
\text { Stability }\end{array}$ & $\begin{array}{ll}\text { - } & \text { Regime shift (Party change) } \\
\text { - } & \text { Regime shift (Systemic Change) } \\
\text { - } & \text { Political/parliamentary unrest } \\
\text { - } & \text { Government Level instability } \\
\end{array}$ & 20 & 5 & 2.42 & 15.94 \\
\hline 15 & $\begin{array}{l}\text { Political } \\
\text { Instability }\end{array}$ & Social unrest & $\begin{array}{l}\text { - } \text { Political instability } \\
\text { - Social tensions } \\
\text { - } \\
\text { Election upheaval }\end{array}$ & 20 & 5 & 2.23 & 21.39 \\
\hline 16 & $\begin{array}{l}\text { Socio- } \\
\text { economic }\end{array}$ & $\begin{array}{l}\text { Organized } \\
\text { Crime }\end{array}$ & $\begin{array}{l}\text { - } \text { Organized Crime } \\
\text { - Gang violence } \\
\end{array}$ & 12 & 3 & 2.40 & 13.40 \\
\hline 17 & $\begin{array}{l}\text { Political } \\
\text { Instability }\end{array}$ & Terrorism & $\begin{array}{ll}\text { - } & \text { Terrorism (Hostage) } \\
\text { - Terrorism (targeting affiliated } \\
\text { suppliers) }\end{array}$ & 12 & 3 & 2.25 & 22.92 \\
\hline 18 & $\begin{array}{l}\text { Policy } \\
\text { Predictability }\end{array}$ & $\begin{array}{l}\text { Predictability } \\
\& \\
\text { transparency } \\
\text { of tax regime }\end{array}$ & $\begin{array}{l}\text { - Changes in business taxes } \\
\text { - } \quad \text { Lack of transparency of taxation } \\
\text { - Predictability of taxes }\end{array}$ & 12 & 3 & 1.43 & 20.83 \\
\hline 19 & Legal Predict & $\begin{array}{l}\text { Policy } \\
\text { Change on } \\
\text { foreign } \\
\text { ownership } \\
\end{array}$ & $\begin{array}{l}\text { - Unpredictability of foreign } \\
\text { ownership }\end{array}$ & 4 & 1 & 3.43 & 12.50 \\
\hline 20 & $\begin{array}{l}\text { Policy } \\
\text { Predict }\end{array}$ & $\begin{array}{l}\text { Revoked } \\
\text { subsidies }\end{array}$ & - Revoked government subsidies & 4 & 1 & 2.75 & 11.11 \\
\hline
\end{tabular}

The Principal Components Analysis (PCA) helped to capture which construct categories are associated most strongly with the outsourcing activities. The information is condensed and summarized in Figure 1, which presents a biplot illustrating how well the various activity types are defined by the political risk constructs elicited from the interview process. The figure represents the scores for the three types of activity (ITP, BPO and KPO) as points, while the vectors represent the coefficients of the different political risks on the principal components. In this figure, the axes (Comp 1 and Comp2) are the two dimensions that span the most variation in the data. To determine the importance of a variable in PCA, Stevens (2002) recommends an absolute threshold of 0.3 , and 0.722 for small samples. From Figure 1 it can be seen that all variables have higher values than both thresholds indicating that they are well defined and therefore none of them need to be ignored. The same reasoning applies to the activity type and hence it is assumed that the activity. Finally, the distance from the activity type to the given constructs indicates how defined the type is by each political risk. 


\section{Figure 1: Principal Components Analysis (PCA) Plot - Offshoring activity type}

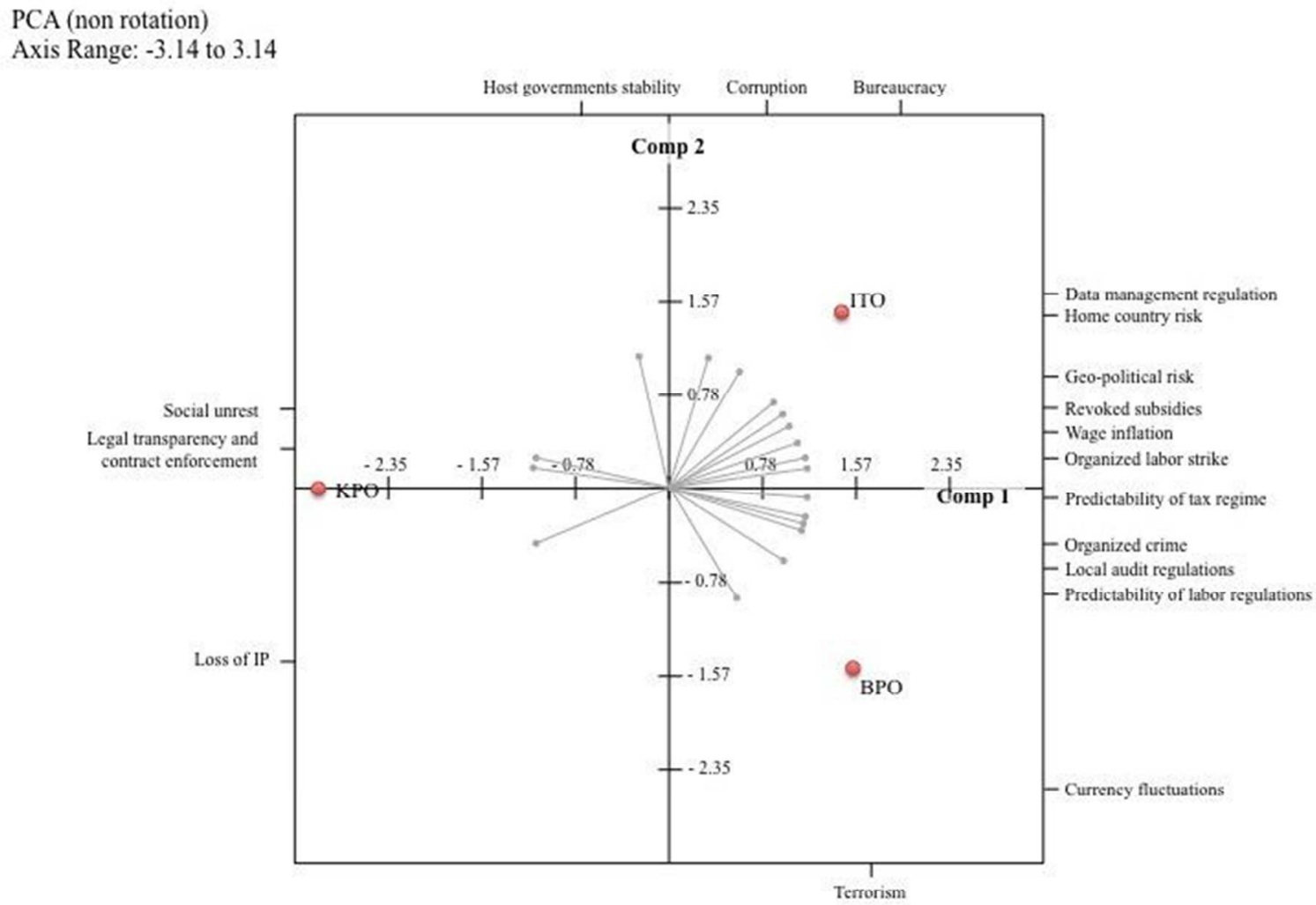

The survey results were stratified in accordance with frequency of mention and associated perceived impact on the offshoring engagement. Table 6 captures the stratification of survey results across activity type (ITO, BPO and KPO). The table helps to highlight the differences in political risk perceptions according to different offshoring activities. 
Table 6: Stratification across offshoring activity types

\begin{tabular}{|c|c|c|c|c|c|c|c|}
\hline \multirow{2}{*}{\multicolumn{2}{|c|}{$\begin{array}{l}\text { Offshoring (Total) -Frequency and perceived impact of political risk } \\
\text { manifestations }\end{array}$}} & \multicolumn{2}{|c|}{$\begin{array}{c}\text { (BPO) Cases } \\
(\mathrm{N}=32,12 \text { Grids })\end{array}$} & \multicolumn{2}{|c|}{$\begin{array}{c}\text { (ITO) Cases } \\
\text { (N=33,13 Grids) }\end{array}$} & \multicolumn{2}{|c|}{$\begin{array}{c}\text { (KPO) Cases } \\
(\mathrm{N}=26,9 \text { Grids })\end{array}$} \\
\hline & & \multirow[b]{2}{*}{ Freq. } & \multirow{2}{*}{$\begin{array}{l}\text { Perceived } \\
\text { Impact } \\
(1-5)\end{array}$} & \multirow[b]{2}{*}{ Freq. } & \multirow{2}{*}{$\begin{array}{l}\text { Perceived } \\
\text { Impact } \\
(1-5)\end{array}$} & \multirow[b]{2}{*}{ Freq. } & \multirow{2}{*}{$\begin{array}{l}\text { Perceived } \\
\text { Impact } \\
(1-5)\end{array}$} \\
\hline $\begin{array}{l}\text { Political Risk } \\
\text { Category }\end{array}$ & Sub-category Political Risk & & & & & & \\
\hline $\begin{array}{l}\text { Client Country } \\
\text { Political Risk }\end{array}$ & Home-Country Risk & $33.3 \%$ & 2.9 & $38.5 \%$ & 3.1 & $22.2 \%$ & 2.6 \\
\hline Policy Predictability & $\begin{array}{l}\text { Change of data management regulatory } \\
\text { framework }\end{array}$ & $41.7 \%$ & 2.7 & $23.1 \%$ & 3.3 & $44.4 \%$ & 1.9 \\
\hline Institutional Capacity & Corruption & $41.7 \%$ & 2.4 & $23.1 \%$ & 3.4 & $55.6 \%$ & 2.7 \\
\hline Legal Predictability & Loss of IP & $25.0 \%$ & 2.6 & $38.5 \%$ & 2.4 & $44.4 \%$ & 2.9 \\
\hline Political Instability & Host Government Stability & $33.3 \%$ & 1.2 & $23.1 \%$ & 3.75 & $11.1 \%$ & 3.0 \\
\hline Political Instability & Social unrest & $33.3 \%$ & 2.1 & $23.1 \%$ & 2.3 & $11.1 \%$ & 3.0 \\
\hline Policy Predictability & Predictability of labour regulations & $58.3 \%$ & 3.4 & $23.1 \%$ & 2.5 & 0 & 0 \\
\hline Macro-economic & Currency Fluctuations & $41.7 \%$ & 2.3 & $23.1 \%$ & 1.5 & $11.1 \%$ & 1.0 \\
\hline Legal Predictability & Legal Transparency \& Contract enforcement & $16.7 \%$ & 1.8 & $15.1 \%$ & 2.0 & $22.2 \%$ & 2.9 \\
\hline Policy Predictability & Predictability \& transparency of tax regime & $16.7 \%$ & 1.4 & $15.1 \%$ & 1.4 & 0 & 0 \\
\hline Socio-economic & Wage Inflation & $33.3 \%$ & 3.0 & $23.1 \%$ & 3.3 & 0 & 0 \\
\hline Socio-economic & Organized labour Strike & $41.7 \%$ & 2.9 & $38.5 \%$ & 2.9 & 0 & 0 \\
\hline Socio-economic & Organized Crime & $16.7 \%$ & 2.5 & $23.1 \%$ & 2.0 & 0 & 0 \\
\hline Political Instability & Terrorism & $25.0 \%$ & 2.5 & $23.1 \%$ & 2.0 & $11.1 \%$ & 2.0 \\
\hline Institutional Capacity & Host country bureaucracy & 0 & 0 & $38.5 \%$ & 2.3 & $55.6 \%$ & 3.4 \\
\hline Political Instability & Geo-political Risk & $25.0 \%$ & 2.7 & $15.1 \%$ & 3.7 & 0 & 0 \\
\hline Policy Predictability & Local Audit regulations & $8.3 \%$ & 3.3 & $23.1 \%$ & 2.5 & 0 & 0 \\
\hline
\end{tabular}




\section{Discussion}

The purpose of this empirical study was to establish an evidence-based understanding of the meaning of political risk in offshoring engagements and to elicit the main risk factors and perceived impact on operations. In this section we discuss the empirical findings in relation to the extant literature.

\subsection{Political risk manifestations in offshore outsourcing}

The research led to the identification of 20 industry specific political risk constructs, of which 5 constructs are considered key categories (as shown in top section of Table 5). The analysis indicates that the single largest political risk concern for offshoring companies pertains to home/client-country political fall-out, or change of home country regulatory frameworks with implications for the offshoring business model. The home-risk category received the highest frequency score at $48 \%$ and the highest impact score to match at 3.21 (on a scale from 1-5). This places home-country risk as a dominant political risk concern for the offshore industry. The risk manifestations elicited from the interviews highlighted negative media, or clashes with powerful workers unions, with potential for reputational damage, as the main concern. The interviewees expressed less concern with the policies themselves, but more the unpredictability of application and constant changes, making it difficult to develop and maintain realistic costing models.

Two other Policy Predictability sub-categories: predictability of labour regulations and the risk of changes of data management regulatory frameworks received high frequency and impact scores at 32\%/3.06 and 40\%/2.9 respectively. The former refers to restrictive labor laws or country specific HR regulations that need to be managed. As one interviewee noted "labor management has both cost and pricing implications, including exposure to possible reputational issues" (Interviewee\#4). Factors related to data management also highlight the impact on business 'as new regulations emerge the pricing structure changes due to the new data retention and licenses requirements' (Interviewee\#8). Again the risk for business was the perceived unpredictability of regulations on data security compliance, which makes it difficult for businesses to maintain price structures. 
Host country bureaucracy also a high frequency score at $48 \%$ and an impact score at 3.06. This finding implies that political risk emanating from local institutions is one of the single highest concerns in the host country environment. Other concerns included import/export clearance procedures, delays in approval processes, licencing regimes, and processing of visa applications for expatriates.

Corruption was mentioned frequently at $40 \%$, and had an impact score of 2.7 , however, it was mainly attributed to low-level operations at destination, rather than perceived as a strategic concern. In fact, one interviewee stated that corruption did not tend to emerge as an issue 'because these clients come from North America and supplier know it is just not the business culture here' (Interviewee\#18). The main concern with corruption appeared to revolve more around management exposure and potential reputational risk. Finally, the political instability risk categories, mostly associated with political risk analysis, were rated at $20 \%$ in terms of Host Government Stability and Social Unrest respectively. While both were frequently mentioned, the perceived impact of these sub-categories was below the 2.5 average score threshold.

Another salient socio-economic factor was organized labor strikes with a frequency of $24 \%$ and impact factor of 3.17. This encompasses national or state strikes, particularly those affecting transport infrastructure, as well as union activities on-site; "An organized labor strike within the transportation sector, like often takes place in India, will disrupt service supply as the suppliers staff are unable to come to work" (Interviewee \#17).

Another potentially significant factor in terms of frequency score pertains to Loss of Intellectual Property (IP) at 40\% frequency of mention level and 2.21 impact score. However, this category has a below average AVN which questions the reliability of the metric. Nevertheless, the notion of IP loss was often mentioned in terms of a general breach of confidentiality through the use of external suppliers and therefore is worth mentioning. One interviewee stated, 'In fact IP is less a concern because the regulations are pretty clear on that and the clients are protected upfront. The big area is privacy of the client or the client customers. And that is why legislation that exists keeps evolving. I guess the challenging part of that, as regulations evolve; the service provider has to evolve their practice to be compliant with those legislations' (Interviewee\#18). Other practitioners stressed that loss of IP was a major consideration leading to the necessity of tactics such as service dissection, i.e. 
services being processed at various independent sites, suggesting that concern relating to IP loss be product and service type specific. The IP infringement issue is also linked to legal predictability, and particularly contract enforcement abilities, in a given offshore setting. With a frequency rating of $36 \%$ the potential inability to enforce contracts through local institutions, either due to lack of institutional capacity and prolonged processes or simply due to lack of political will. The notion that 'your contract is only as good as your ability to enforce it' is apparent.

While a number of the factors identified had low frequency of mention or below average ANVs. It is important to note that the findings suggest that a narrow conceptualization of the external uncertainty construct of political risk is insufficient to capture the perceived risk exposure of the offshore service industry and needs to be extended with more granularity on the types and nature of risk exposure.

\section{$5.2 \quad$ The impact of offshore type on political risk perceptions}

The research reveals similarities and differences in frequency and impact of risk categories across the three offshoring activity types i.e. IPO, BPO and KPO (Table 6). The first observation is that the frequency scores are relatively similar between BPO and ITO engagements. Both BPO and ITO have high frequency and impact ratings on risk relating to labour force liabilities including: Predictability of labour regulations, Wage Inflation and Organized Labour Strike. Similarly, Home Country Risk appears more prevalent for both typologies. Furthermore, ITO appears more concerned with Loss of IP and Bureaucracy issues. Based on the sample size of $32 \mathrm{BPO}$ and 33 ITO engagement cases the findings do not suggest major discrepancies between BPO and ITO engagements in terms of frequency ratings.

In terms of comparing the ITO and BPO findings on perceived impact of political risk the findings indicate a higher level of discrepancy (Table 6). While both categories rate Organized Labour Strike as the main impact category, BPO is perceived to be more impacted by Predictability of Labour Regulations, Legal Transparency and Local Audit Regulations, while ITO is perceived to be impacted more strongly by Geo-political Risk, Home-Country Risk, Host Government Stability and Wage Inflation. 
The second observation is that KPO engagements are more associated with host country Bureaucracy, IP Loss, Change of Data Management Frameworks and Corruption. This was further confirmed by the Principal Components Analysis (PCA) highlighting a stronger association with IP loss and legal transparency and contract enforcement concerns. The findings suggest that political risk exposure is closely linked with the business activity and the associated exposure to specific risk manifestations.

The findings also suggest that there are limited discrepancies on political risk experiences in terms of frequency ratings between BPO and ITO engagements, both highlighting organized labour strike as one of the main impact categories. However, compared with KPO, it was possible to observe a more marked scope shift towards concerns relating to regulatory frameworks and contract enforcement, and greater impact of potential IP loss, contract enforcement limitations and legal predictability.

The association of KPO with loss of IP, policy change on foreign ownership and contract enforcement risks, suggests that institutional capacity i.e. legal enforcement of IP rights and contracts becomes increasingly important as the value of product or service is enhanced. As stated, 'Most of the high-end $R \& D$ or IP type development or intellectual property type development happens in in-house locations So most of the high-end work is done internally with their own employees and their own buildings - everything is their own - only thing is that it may happen to be in an offshore location'. The reason they do that is they don't trust others to do it-it is about whether they can expose that and still have the right control (Interviewee \#17).

Hence the findings suggest that for purely transactional work most firms are comfortable outsourcing to third-party, while for high-end activities they prefer to keep the process internal, supporting the TCE premise of internalization to avoid supplier opportunistic behaviour and minimization of associated transaction costs. Overall, the findings suggest that political risk exposure is specific to the nature of the offshored business activity and what risk management steps have been taken to address the exposure. The findings further suggest that these specific risk exposures be considered in the context of low versus high value service delivery as a key distinction for political risk exposure. 


\subsection{The impact of risk management experience}

The qualitative components of the study highlight an apparent contradiction in the sense that political risk within the offshore outsourcing industry remains a relevant concern, and is perceived as something that can be managed, while there is limited evidence of actual proactive risk management taking place.

The concept of political risk and the implications for operations appear to remain elusive. As expressed by one interviewee, the implications of political risk 'could be a protest, or not being able to go to work for a time, or basically not be able to operate locally. It could also be power outages which is not necessarily political, but could be politically motivated.' (Interviewee \#16). From these perceptions the concept of political risk and its implications are difficult to establish. The main focus seems to be on the monitoring of traditional risk constructs, like political stability and social unrest indicators, rather than factors like homecountry risk pertaining to policy changes, institutional capacity and integrity of legal frameworks.

In terms of active management of political risk, the interviews yielded a high level of variability. Some companies are rather disengaged, as stated: '...once the relationship is established we don't monitor. Unless there is something in the press... otherwise we won't notice (Interviewee \#16). Conversely, another interviewee stated that '...it is actually a big piece of our activities in terms of monitoring these things and developing the risk management plans and implementing those plans.' (Interviewee\#11). Others recognized its importance, but with a degree of scepticism, 'Ultimately my sense is that politics does matter and it is something they are cognizant of and something they work on and actively try to manage. However, I have rarely seen any decision ultimately reversed due to political risk - they slow down but they don't get reversed (Interviewee\#19).

The discrepancy in application of risk management approaches could be attributed to firm specific moderators that determine the risk management capacity and risk appetite. The risk appetite, or rather the perceived ability to manage risks, appears to be linked to the experience of the given firm. As stated, the understanding of risk management varies 'by and large, the larger the client and if they have been exposed 5-10 years, they have a sense of maturity on this. For a new client it is an uphill task and a new thing - and marked by lack of rigor and clarity of how to deal with this (Interviewee\#17). These suggest that previous 
experience and exposure to political risk has a significant impact on the risk appetite of the executives and the firm's capacity to manage risks.

\section{Conclusions}

This exploratory empirical investigation offers several contributions to both theoretical and practical knowledge. First, it supports the call for re-conceptualizing of the TCE definition of political risk, in the context of offshore outsourcing, to include a broader operationalization of governance characteristics like institutional capacity, policy predictability and legal enforcement capacities, rather than maintaining a narrow focus on political stability indexes. Organizations need to take these factors into consideration when evaluating the risks in global operations, this is particularly relevant to the development of new real time data-driven approaches, such as HP's Geographic analytics (Acksteiner and Trautmann, 2013) and IBM's supply chain analytics (Busch, 2015).

From a theoretical perspective the re-operationalization of the external environmental risks will allow a more diversified analysis of a firm's offshoring choices. As indicated, the research highlights the need to expand the conceptualization and operationalization of formal external uncertainty as defined by TCE, and encourage research to measure external uncertainty by other political dimensions such as government effectiveness, regulatory quality and control of corruption in line with Slangen and Tulder (2009). From a practical perspective a re-conceptualization of political risk will require a broader scope of monitoring, including an engagement with potential home country specific political fall-out or policy changes. Furthermore, the analysis and weighting of the political risk manifestation types across offshoring activities allows for more accurate industry-specific location decisions and risk monitoring throughout the offshoring engagement. The intention is to provide a weighted risk index to guide location decisions within the industry.

A second contribution concerns the identification of the moderating effect of specific outsourcing activity (BPO, ITO and KPO) on risk perceptions. BPO and ITO engagements appear to have many similarities, particularly on risk relating to labour force liabilities including: Predictability of Labour Regulations, Wage Inflation and Organized Labour Strike as well as on, Home Country Risk considerations. However, the risks associated with KPO 
engagement appear to be different, emphasizing risk categories such as IP loss, Change of Data Management frameworks, Contract enforcement, and concerns with Corruption. This suggests that IP rights and contracts become increasingly important as the value of the product, or service, is enhanced.

The findings also suggest that the offshoring industry generally adopts an avoidance strategy in regards to traditional political risk (i.e. political instability and social unrest), while expecting to manage other non-traditional risks. The notion that political risk can be managed suggests that the firm's risk adaptive behaviour, through active risk management should be explored, as the firm's perception of its ability to manage certain risk, will impact on the perception of overall uncertainty related to the given engagement.

This study uses managers' perceptions of risks, which have been shown to be a good indicator of how often that risk actually occurs in the form of supply disruptions (Zsidisin and Wagner, 2010). To guard against using unreliable perceptions of risk, this study was limited to risk perceptions of the first or second tier suppliers, and the associated supply market, and perceptions of risks from the extended supply chain were not included.

Repertory grid analysis suffers from some limitations as it elicits constructs and perceived impact that are specific to the individual, and therefore it may not be possible to derive results that are representative of a population. Similarly, the fact that critics of RGT highlight that constructs change over time and hence are time specific highlights the question of reliability of the results. The extracted data therefore needs to be understood to be time specific of nature. For these reasons the study should be viewed as exploratory work, which has elicited constructs which can be validated using surveys of larger samples or by using secondary data that can lead to more reliable and generalizable results. This could involve the combination of a number of global indices, such as the Global Competitive Index (GCI), the Worldwide Governance Indicators (WGI), Ease of doing business index (World Bank), to help cover different aspects of political risk.

Despite the limitations mentioned above, we find that the use of RGT provides a clear trail of evidence which is available for reanalysis by other researchers, and hence enhances transparency and provides additional evidence concerning the importance and complexity of evaluating political risk for both home and host country. 
Another avenue for further research is the integration of risk management ability (or perceived ability) into the overall function of entry mode uncertainty determination in order to explore the (risk) adaptive behaviour patterns of firms, as well as the implications on entry mode strategies. Secondly, while this research suggested that the impact of home political risk was sector specific and regional, it would be valuable to further explore the actual impact on offshoring decisions and determine whether the risk is mostly rhetoric, or real, in its consequence. Finally, the findings suggests that a review of the impact of political risk considerations in offshoring entry modes would need to include measure of moderators pertaining to firm experience and business volume. The findings therefore suggest that the premise of TCE alone may be insufficient to explain a firm's offshoring decisions and call for further research to investigate the impact of political risk perceptions on transaction costs.

\section{References}

Acksteiner, J., Trautmann, C. 2013. Geographic analytics: How HP visualizes its supply chain. Supply Chain Management Review, 17(1): 28-35.

Agarwal, J. and D. Feils. 2007. "Political Risk and the Internationalization of Firms: An Empirical Study of Canadian-based Export and FDI Firms." Canadian Journal of Administrative Sciences 24(3): 165-181.

Alon, I. and T. T. Herbert. 2009. "A stranger in a strange land: Micro political risk and the multinational firm.” Business Horizons 52(2): 127-137.

Altay, N. and Ramirez, A. (2010), Impact of disasters on firms in different sectors, Journal of Supply Chain Management, 46(4), 59-80.

Ambulkar, S., Blackhurst, J. and Grawe, S. (2015) Firm's resilience to supply chain disruptions: Scale development and empirical examination, Journal of Operations Management, 33-34: 111-122.

Anderson, E. and H. Gatignon. 1986. "Modes of Foreign Entry: A Transaction Cost Analysis and Propositions." Journal of International Business Studies 17(3): 1-26.

Aubert, B. A., S. Rivard and M. Patry. 2004. "A transaction cost model of IT outsourcing." Information and Management 41(7): 921-932.

Brewer, T. L. 1983. "The Instability of Governments and the Instability of Controls on Funds Transfers by Multinational Enterprises: Implications for Political Risk Analysis." Journal of International Business Studies 14(3): 147-157.

Brewer, T. L. 1993. "Trends in International Business, Thought, and Literature: The Past and Future of Political Analysis for International Business." International Executive 35(6): 539548. 
Busch, J. 2015. "When Watson Meets Procurement - IBM Uses Big Data to Tackle Big Supply Challenges"_Spend Matters, - June 5, 2015 (available from http://spendmatters.com/ 2015/06/05/when-watson-meets-procurement-ibm-uses-big-data-to-tackle-big-supplychallenges/; last visited 07/11/16)

Busse, M. and C. Hefeker. 2007. "Political risk, institutions and foreign direct investment." European Journal of Political Economy, 23(2): 397-415.

Christopher, M., C. Mena, C., O. Khan and O. Yurt. 2011. "Approaches to managing global sourcing risk." Supply Chain Management: An International Journal, 16(2), 67-81.

Christopher, M., and H. Peck. 2004. "Building the Resilient Supply Chain." The International Journal of Logistics Management 15: 1-14.

Coplin, W. D. and M.K. O'Leary. 1983. "Political Risk Analysis for Extractive Industries." Strategy and Leadership 11(2): 16.

Edmonson, A. C. and S.E. McManus. 2007. "Methodological Fit in Management Field Research." Academy of Management Review, 32(4): 1155-1179.

Ellis, S.C., Henry, R.M. and Shockley, J. (2010) Buyer perceptions of supply disruption risk: A behavioral view and empirical assessment, Journal of Operations Management, 28: 34-46.

Ellram, L. M., W. L. Tate and C. Billington. 2008. "Offshore outsourcing of professional services: A transaction cost economics perspective." Journal of Operations Management 26(2) 148-163.

Erramilli, M. K. 1992. "Influence of some external and internal environmental factors on foreign market entry mode choice in service firms." Journal of Business Research 25(4): 263276.

Gholami, S. 2012. "Critical Risk Factors in Outsourced Support Projects of IT.” Journal of Management Research 4(1): 1-13.

Goffin, K., 1994. Understanding Customers' Views: An Example of the Use of Repertory Grid Technique. Management Research News, 17(10/11), pp.17-28.

Goffin, K., Lemke, F. and Szwejczewski, M. 2006. An exploratory study of 'close' suppliermanufacturer relationships. Journal of Operations Management, 24(2): 189-209.

Goffin, K. 2009. "Repertory Grid Technique", In Essential Skills for Management Research, edited by in D. Partington, 199-225. Second Ed., Sage Publications, London.

Goffin, K., J. Raja, B. Claes, M. Szwejczewski and V. Martinez. 2012. "Rigor in qualitative supply chain management research: lessons from applying repertory grid technique." International Journal of Physical Distribution and Logistics Management, 42(8): 804-827.

Goodman, S. E. and R. Ramer. 2007. "Identify and Mitigate the Risks of Global IT Outsourcing." Journal of Global Information Technology Management 10(4): 1-6.

Grappi, S., Romani, S. and Bagozzi, R.P., 2013. The effects of company offshoring strategies on consumer responses. Journal of the Academy of Marketing Science, 41(6), pp.683-704.

Griffin, A. and Hauser, J.R., 1993. The voice of the customer. Marketing Science, 12(1), pp.127.

Hahn, E. D., J. P. Doh and K. Bunyaratavej. 2009. "The Evolution of Risk in Information Systems Offshoring: the Impact of Home Country Risk, Firm Learning, and Competitive Dynamics." MIS Quarterly 33(3) 597-616.

Hendricks, K. B., and V. R. Singhal. 2003. "The effect of supply chain glitches on shareholder wealth." Journal of Operations Management 21(5), 501-522. 
Ho, W., T. Zheng, H. Yildiz, and S. Talluri. 2015. "Supply chain risk management: a literature review." International Journal of Production Research 53:16, 5031-5069,

Herath, T. and R. Kishore. 2009. "Offshore Outsourcing: Risks, Challenges, and Potential Solutions." Information Systems Management 26(4): 312.

Jolliffe, I., 2002. Principal Component Analysis. John Wiley \& Sons, Ltd.

Kelly, G.A. 1955. The Psychology of Personal Constructs. New York: Norton

Kesternich, I. M. and Schnitzer. 2010. "Who is afraid of political risk? Multinational firms and their choice of capital structure." Journal of International Economics, 82(2): 208-218.

Kobrin, S. J. 1979. "Political Risk: A Review and Reconsideration." Journal of International Business Studies, 10(1): 67.

Kobrin, S. J. 1981. “Political Assessment by International Firms: Models or Methodologies?” Journal of Policy Modeling 3(2): 251.

Kumar, S. and M. Sosnoski. 2009. "The Effects of China's Economic Growth on Domestic and International Supply Chains: Assessing the Risks." Supply Chain Forum,10(2): 10-24.

Kumar, S., A. Kwong, and M. Chandan. 2009. "Risk mitigation in offshoring of business operations." Journal of Manufacturing Technology Management 20(4): 442-459.

Lacity, M.C., Willcocks, L.P. and Rottman, J.W., 2008. Global outsourcing of back office services: lessons, trends, and enduring challenges. Strategic Outsourcing: An International Journal, 1(1): 13-34.

Leavy, B. 1984. "Assessing Country Risk for Foreign Investment Decisions." Long Range Planning 17(3): 141-150.

Lemke, F., Clark, M. and Wilson, H., 2011. Customer experience quality: an exploration in business and consumer contexts using repertory grid technique. Journal of the Academy of Marketing Science, 39(6), pp.846-869.

Lemke, F., Goffin, K. and Szwejczewski, M., 2003. Investigating the meaning of suppliermanufacturer partnerships: an exploratory study. International Journal of Physical Distribution \& Logistics Management, 33(1), pp.12-35.

Lewin, A.Y. and C. Peeters. 2006. "Offshoring work: Business hype or the onset of fundamental transformation?" Long Range Planning, 39(3): 211-239.

Li, G., Fan, H., Lee, P.K.C. and Cheng, T.C.E. (2015). Joint supply chain risk management: an agency and collaboration perspective. International Journal of Production Economics 164, 83-94.

Liuhto, K., M. Heikkilä and E. Laaksonen. 2009. "Political risk for foreign firms in the Western CIS -- An analysis on Belarus, Moldova, Russia and Ukraine." Journal for East European Management Studies 14(4): 395-407.

López-Duarte, C. and M.M. Vidal-Suárez. 2010. External uncertainty and entry mode choice: Cultural distance, political risk and language diversity." International Business Review 19(6): 575-588.

Marsden, D. and Littler, D., 2000. Exploring consumer product construct systems with the repertory grid technique. Qualitative Market Research: An International Journal, 3(3), pp.127-144.

McIvor, R. 2009. "How the transaction cost and resource-based theories of the firm inform outsourcing evaluation." Journal of Operations Management 27: 45-63. 
Madhok, A. and S. Tallman. 2006. "New directions in global and international strategy research: Beyond the transnational." Journal of International Management, 12(1): 131-133.

Miller, K. D. 1992. "A Framework for Integrated Risk Management in International Business." Journal of International Business Studies 23(2): 311.

Oetzel, J. 2005. "Smaller may be beautiful but is it more risky? Assessing and managing political and economic risk in Costa Rica." International Business Review 14(6): 765-790.

Rao, S. and T. J. Goldsby. 2009. "Supply chain risks: a review and typology." International Journal of Logistics Management 20(1): 97-123.

Robock, S. H. 1971. "Political Risk: Identification and Assessment." Columbia Journal of World Business 6(4): 6.

Schoenherr, T. 2010. "Outsourcing decisions in global supply chains: an exploratory multicountry survey." International Journal of Production Research 48(2), 343-378.

Senior, B. and Swailes, S., 2004. The dimensions of management team performance: a repertory grid study. International Journal of Productivity and Performance Management, 53(4), pp.317-333.

Slangen, A. H. L. and R. J. M. v. Tulder. 2009. "Cultural distance, political risk, or governance quality? Towards a more accurate conceptualization and measurement of external uncertainty in foreign entry mode research." International Business Review 18(3): 276-291.

Smith, M.E., 2008. Psychological Foundations of Supply Chain Risk Management. In Supply Chain Risk - A Handbook of Assessment, Management and Performance. Edited by: Zsidisin G.A. and B. Ritchie, 219-234. First Edition. New York: Springer.

Stevens, J. P. 2002. Applied multivariate statistics for the social sciences (4th ed.). Hillside, NJ: Erlbaum

Stewart, V., Stewart, A. and Fonda, N., 1981. Business applications of repertory grid. McGrawHill Companies.

Straub, S. 2008. "Opportunism, corruption and the multinational firm's mode of entry." Journal of International Economics 74(2): 245-263.

Tate, W.L. and L.M. Ellram. 2009. "Offshore outsourcing: a managerial framework." Journal of Business and Industrial Marketing 24(3/4): 256-268.

Tukamuhabwa, B.R, Stevenson, M., Busby, J. and Zorzini, M. (2015) Supply chain resilience: definition, review and theoretical foundations for further study, International Journal of Production Research, 53:18, 5592-5623

Tummala, R., and T. Schoenherr. 2011. "Assessing and Managing Risks Using the Supply Chain Risk Management Process (SCRMP)." Supply Chain Management: An International Journal 16: 474-483.

Vandevelde, A. and Van Dierdonck, R., 2003. Managing the design-manufacturing interface. International Journal of Operations \& Production Management, 23(11), pp.1326-1348.

Wade, J. 2005. “Political Risk in Eastern Europe.” Risk Management, 52(3): 24-29.

Wagner, S.M., Bode, C. (2008). An empirical examination of supply chain performance along several dimensions of risk. Journal of Business Logistics, 29(1), 307-325.

Walker, G. and D. Weber. 1984. "A transaction cost approach to make-or-buy decisions" Administrative Science Quarterly 29(3): 373-391. 
Weiss, R. M. and A. Azaran. 2007. "Outward Bound: Considering The Business And Legal Implications Of International Outsourcing." Georgetown Journal of International Law 38(3): 735-753.

Williamson, O. E. 1995. "Hierarchies, Markets and Power in the Economy in Economy: An Economic Perspective." Industrial and Corporate Change 4(1): 21-49.

Williamson, O. E. 2002. "The Theory of the Firm as Governance Structure: From Choice to Contract." Journal of Economic Perspectives 16(3): 171-195.

Williamson, O. E. 2008. "Outsourcing: Transaction Cost Economics and Supply Chain Management." Journal of Supply Chain Management 44(2): 5-16.

Williamson, O. E. 2010. "Transaction Cost Economics: The Natural Progression." Journal of Retailing, 86(3): 215-226.

Wilson, M.C. (2007). The impact of transportation disruptions on supply chain performance. Transportation Research Part E: Logistics and Transportation Review, 43(4): 295-320.

Youngdahl, W. and Ramaswamy, K., 2008. Offshoring knowledge and service work: A conceptual model and research agenda. Journal of Operations Management, 26(2), pp.212221.

Zhao, H., Y. Luo and T. Suh. 2004. "Transaction cost determinants and ownership-based entry mode choice: a meta-analytical review." Journal of International Business Studies 35(6): 524-544.

Zsidisin, G. A., S. A. Melnyk, and G. L. Ragatz. 2005. "An Institutional Theory Perspective of Business Continuity Planning for Purchasing and Supply Management." International Journal of Production Research 43 (16): 3401-3420.

Zsidisin, G.A. and Wagner, S.M. (2010). Do perceptions become reality? The moderating role of supply risk resiliency on disruption occurrence. Journal of Business Logistics, 31(2), 1-20.

Zsidisin, G.A., B N. Petkova and D. Lammertjan. 2016. "Examining the influence of supply chain glitches on shareholder wealth: does the reason matter?" International Journal of Production Research, 1-14.

Zuckerman, M., 2007. Sensation seeking and risky behaviour. Washington, DC, US: American Psychological Association. 


\section{Appendix 1: Repertory Grid Interview Script}

Explanation to the Interviewee:

Introduction and personal statement

Interview administration instructions

Biographical data

Position and title in the company, plus years of experience

Description of the company offshoring structure and activities

Role in the design and management of offshoring activities

\section{Elements - Identification of Constraints (or Risk):}

Based on the wide political risk definition (shared with the interviewee by email and reiterated at interview) the interviewee names six offshoring engagements that was affected by some level of political impact.

Write the constraints (or risks) on random pre-numbered cards (I.e. $5 ; 1 ; 4 ; 3 ; 2 ; 6$ )

\section{Constructs and pole constructs - Present triad and collect constructs:}

The interviewee is asked: "Please think about how two of these engagements are similar and different from the $3^{\text {rd }}$ in terms of political risk exposure.

The political risk construct is defined - Noting that the meanings of the constructs need to be probed

\section{Rating of Constraints (or Risks):}

Rate the triad elements on pre-decided scale against construct, and then rate all other elements (constraints) and enter on pre-prepared grid against a 1-5 scale. 